\title{
A LITERATURA DOS JAPONESES NO BRASIL E A QUESTÃO DO CABOCLO
}

Masahiko Nishi ${ }^{1}$

Em julho de 1936, Shimazaki Tôson (1872-1943) partiu do porto de Kôbe com destino à Buenos Aires com a incumbência de representar o Japão no $14^{\circ}$ Congresso Mundial do PEN Clube. A viagem que durou cerca de meio ano - de julho a janeiro do ano seguinte - seguiu a rota sul via Ásia, África, América do Sul, América do Norte e Europa. As memórias desta viagem foram publicadas na revista Kaizô (Reconstrução) em série e, posteriormente, reeditadas num livro intitulado Jun 'rei (Peregrinação, 1940), considerado uma obra representativa da fase final de sua vida.

Shimazaki Tôson era natural da região de Shinshû e não poderia estar indiferente diante da possibilidade de conhecer países como o Brasil, a Coréia e a Manchúria, locais de emigração de seus compatriotas. Há de se convir que o desejo de ver com os próprios olhos o destino daqueles que outrora partiram deveria ser grande, uma vez que o protagonista de sua obra Hakai (A quebra de um mandamento, 1906) também não resistiu às propagandas que incitavam os japoneses a emigrarem e decidiu ir para o Texas em busca de trabalho.

Tôson, sua esposa e seu amigo Arishima Ikuma (1882-1974) embarcaram no navio Rio de Janeiro-maru juntamente com 850 emigrantes com destino ao Brasil e Paraguai: um velho escritor em sua viagem de "peregrinação" e os emigrantes com destino à América do Sul. Enquanto que a "peregrinação" de Shimazaki Tôson tinha como premissa seguir as pegadas deixadas pelos japo-

1 Docente e pesquisador da Universidade Ritsumeikan, Quioto. A primeira versão deste artigo constituiu o texto da palestra proferida em 21 de fevereiro de 2014, no Centro de Estudos Japoneses da USP. 
neses, o mesmo não se poderia dizer em relação aos 850 emigrantes que, como "colonos", foram intencionalmente motivados a viajar em busca de uma tão sonhada "Terra Prometida".

Ao chegar ao porto de Santos, em fins de agosto daquele ano, Tôson - após se despedir dos compatriotas que seriam encaminhados para a Hospedaria dos Imigrantes de São Paulo e, posteriormente, transferidos para o interior do Estado - prosseguiu sua viagem até Buenos Aires e, cumprido a missão oficial, retornou ao Brasil em meados de setembro, desta vez, desembarcando em Santos. Em São Paulo, ele se reuniu informalmente com funcionários do Consulado, alguns representantes da comunidade japonesa e um grupo de poetas locais; ocasião em que gravou poemas na lápide exposta na entrada do Hospital da Beneficência Japonesa (Dôjinkai Nihon Byôin), prevista para ser inaugurada naquele mesmo ano. (Este hospital passou a ser denominado Hospital Santa Cruz, após ter sido confiscado pelo governo brasileiro por ocasião da Segunda Guerra Mundial). Apesar de sua estadia ter sido curta, as reflexões suscitadas nessa viagem foram minuciosamente registradas em Jun'rei (Peregrinação, 1940).

O diário sobre a sua viagem ao Brasil foi publicado nas edições de junho e julho da revista Kaizô (Reconstrução, 1939) e, nele, encontramos o seguinte trecho:

\begin{abstract}
As palavras são enigmáticas. Apesar de a minha viagem ter sido realizada em circunstâncias específicas, posso dizer que a maneira mais rápida e segura de conhecer as coisas é através do emprego que se faz da palavra. No Brasil existe o termo "caboclo". Caboclo é uma alcunha para designar as pessoas que nasceram no país. A despeito de não ter visitado a zona rural, ao escutar a palavra "caboclo", não só me veio à mente a imagem das crianças mestiças como também senti que nela havia uma forte conotação colonizadora. Ouvi dizer que no Brasil os mestiços de negros africanos são extremamente discriminados por aqueles que insistem em promover a discriminação racial. Nesse sentido, se o caboclo não é considerado uma pessoa latino-americana, ele seria, então, um imigrante antigo vindo da África? Seja como for, "caboclo" é uma palavra que jamais esquecerei. Um japonês residente no Brasil me contou que sugeriu o cultivo do milhete a um caboclo que estava com as terras sem plantação. O caboclo concordou dizendo que a ideia era boa e que realmente daria certo, pois já havia tentado antes. O comportamento do caboclo era um dos assuntos comentados até mesmo entre nós viajantes. (Caboclo)
\end{abstract}

Na segunda metade do século XIX, as florestas virgens de São Paulo foram desbravadas num ritmo vertiginoso e a cidade de São Paulo se tornou, em curto espaço de tempo, o mais importante centro econômico do país. O primeiro produto comercial de exportação no período colonial foi o pau-brasil e, após a consolidação do sistema escravagista, deu-se início ao sistema de exploração colonial denominado plantation, centrado no cultivo da cana-de-açúcar e seus destilados. A exploração de metais, pedras preciosas e os recursos naturais como 
a borracha também trouxe riquezas exorbitantes para o Brasil colonial. No entanto, esses produtos que movimentaram a economia brasileira até o século XIX deixaram a natureza exuberante praticamente intocada, a despeito de os missionários jesuítas e os colonos portugueses se fixarem na região costeira do nordeste e trazerem consigo os conhecimentos da civilização ocidental. Nesse contexto, o povo indígena foi obrigado a conviver com os colonos europeus o que resultou não somente a miscigenação como também o desenvolvimento de uma cultura híbrida. Os colonos que chegaram posteriormente passaram a chamar de "caboclos" aqueles cujas feições eram difíceis de serem reconhecidos como nativos ou europeus.

A linguagem utilizada na zona tropical de plantation era o português “crioulo", uma variação da língua praticada pelos escravos negros africanos, mas, a linguagem considerada oficial era aquela usada pelos nativos de São Paulo e região $\mathrm{sul}^{2}$. A subsistência era exclusivamente baseada na caça e na agricultura primitiva, prática herdada pelos índios e, portanto, não dependia da produção agrícola. $\mathrm{Na}$ prática, isso fazia com que o grau de dependência em relação ao comércio de produtos fosse extremamente baixo. A cultura do pão não havia como fincar raízes numa cultura alimentar a base de mandioca, milho e feijão. Obviamente, dentre os paulistas, havia aqueles que foram vendidos para as lavouras do nordeste, assim como havia os mineiros que trabalhavam na exploração do ouro aluvial em pó no interior do país. Por outro lado, os escravos que fugiam do nordeste para a região sul formavam um grupo étnico de cultura híbrida. No entanto, até a introdução da lavoura cafeeira, essas regiões não passavam de terra bruta.

Mas o cenário de São Paulo mudou. Os brasileiros interessados na lavoura cafeeira contratavam os imigrantes italianos como administradores locais e, com a introdução dos caboclos e escravos livres do nordeste como força de trabalho, rapidamente alçaram o Estado de São Paulo como o centro econômico do país. E, na virada do século, com a expectativa de obter uma força de trabalho mais segura e conveniente do que a dos caboclos e baianos é que se possibilitou a entrada maciça de imigrantes japoneses.

De fato, Shimazaki Tôson percebeu que o termo caboclo era impregnado de uma conotação de colonização advinda dessa conjuntura existente no cenário brasileiro. Durante a travessia de Kôbe até a América do Sul, ele sentiu uma melancolia nostálgica ao observar as crianças mestiças mescladas à paisagem das cidades portuárias da Ásia e da África e, posteriormente, passou a associar a imagem do caboclo como um produto da herança histórica do sistema colonial praticado no Ocidente, ou seja, o caboclo era um espécime do sistema colonialista. Shimazaki

2 Darcy Ribeiro. O povo brasileiro. São Paulo: Companhia das Letras, 1995:365. 
Tôson possivelmente não chegou a refletir seriamente sobre a questão de os japoneses de sua época estar migrando para o exterior e que, além de terem seus filhos mestiços na Ásia, havia a promessa de que a Esfera da Co-Prosperidade da Ásia Oriental planejava futuramente recolhê-los. Durante a viagem, ele que visitou o túmulo das prostitutas japonesas denominadas "Karayuki-san" em Singapura, e que chorou diante dele, sequer pensou nos filhos legítimos e nos mestiços que porventura os japoneses fizeram nas mulheres daquele país.

Neste ponto, há de se ressaltar outra questão. O objetivo da "peregrinação" de Shimazaki Tôson não foi o de averiguar os estragos nem tampouco a herança do sistema colonial praticado no Ocidente. $O$ real motivo de sua peregrinação foi seguir os passos deixados pelos japoneses pelo mundo e revelar os pequenos milagres que porventura ali existissem. Shimazaki Tôson não conheceu de fato os caboclos e a vida que levavam, limitando-se a apenas ouvir anedotas contadas pelos japoneses que residiam no Brasil e, certamente, o que sentiu ao escutar a palavra "caboclo" se deve ao modo com que essa palavra era pronunciada na língua japonesa falada na colônia, e foi com essa impressão que ele deixou o Brasil. Mas, será que o fato de ele traduzir o termo "caboclo" como dojin 土人 - termo que em japonês significa "nativo da região" - não seria um modo de ressaltar tanto o exótico sentimento de "colonização" quanto o seu profundo discernimento em relação a essa questão?

Há de se ressaltar que, naquela época, a representação do dojin - (nativo da região) na literatura japonesa escrita no exterior, e que tinham como palco países como Taiwan, Coreia, Sacalina, Manchúria e as ilhas e países dos mares do sul - não se limitava a descrevê-lo como um ser típico de um país estrangeiro. $\mathrm{O}$ dojin representava o que um homem civilizado jamais poderia se tornar, pois a sua imagem era sinônimo do homem decadente. Portanto, a ideologia imperialista incutiu nos homens civilizados a obrigação de eles assumirem a missão de instruir e de educar o dojin. Nesse sentido, o termo dojin foi exaustivamente empregado para reforçar essa missão de defender a fronteira que separa o homem civilizado do não-civilizado; uma palavra com um poder encantatório que foi aceito pela opinião pública sem questionamentos.

O modo de os japoneses no Brasil pronunciarem "caboclo" possuía a mesma entonação da de um japonês do Japão ao pronunciar a palavra dojin. E talvez tenha sido esta a razão de Tôson associar o termo "caboclo" ao sentimento de colonialismo. Os japoneses que foram educados a aceitar e apoiar o eufórico grito de "Datsu-A Nyû-ô" (deixar a Ásia e introduzir o Ocidente) não somente olhavam com desprezo o "caboclo" como também temiam adquirir as más influências de seus costumes, de modo a condenar e insultar sarcasticamente os compatriotas que se tornavam "caboclo". Shimazaki Tôson, ciente da conotação pejorativa do termo dojin - que era muito popular no Japão de sua época - percebeu que o termo 
"caboclo" no Brasil possuía a mesma conotação colonialista e discriminatória existente no Japão.

Os japoneses não eram os únicos que geravam crianças mestiças como os caboclos. Eles incorporavam as maneiras do caboclo de modo espontâneo a ponto de correrem o risco de perderem a honra de serem japoneses, mas isso, ao meu ver, deveria ser considerado como um ato de coragem.

Seis anos antes da viagem de Shimazaki Tôson, Ishikawa Tatsuzô que, naquela época, estava numa fase embrionária para se tornar um escritor, decidiu vir para o Brasil como vice-supervisor dos imigrantes. O relato dessa experiência foi publicado em sua obra Sôbô (1935-1939), obra que o tornou um escritor de grande prestígio. A sua estada no Brasil foi apenas de dois meses. Durante um mês ele permaneceu na cidade de São Paulo, o que significa que o período de permanência na fazenda no norte do Estado foi de apenas um mês.

Mas, ao ler o terceiro capítulo intitulado "Um povo sem voz", logo se percebe que, a despeito de sua curta estada e convivência com os imigrantes japoneses na fazenda, a experiência desse contato foi deveras importante.

Para os que desejam escrever uma obra literária em japonês tendo como cenário o Brasil, queira ou não, Sôbô é um livro de referência. A inserção de palavras japonesas usadas pela colônia no decorrer do texto representa um modelo de "literatura japonesa sobre o estrangeiro" que teve o seu apogeu no início do período Shôwa (1926-1989). Em Sôbô temos, por exemplo, a questão dos imigrantes japoneses veteranos e os novatos; os personagens que vivem na fazenda, $o$ administrador de origem europeia, o camarada caboclo e o uso da língua japonesa e a portuguesa naquele contexto. Cito apenas alguns dos recursos adotados por Ishikawa Tatsuzô para escrever sobre a história dos japoneses no Brasil, uma vez que, aqui, não teríamos tempo para tratar de todos os demais recursos. Após acompanhar durante dois meses os imigrantes como vice-supervisor, Ishizawa Tatsuzô decide retornar para o Japão e, quando menos esperava, se viu trabalhando como escritor. Seria leviano declarar que ele era apenas mais um escritor japonês, pois não existe nenhuma razão concreta para que, desde o início, façamos uma distinção entre um escritor que escreve sobre os japoneses do Brasil no Japão e outro que escreve sobre esse assunto in loco.

Natsu (Onatsu) é a personagem que se pode considerar a heroína da história. Ela é a esposa de fachada de Satô Katsuji. No capítulo 3 ela finalmente chega na fazenda localizada no norte do Estado de São Paulo. Para descrever esse local, Ishikawa Tatsuzô começa por contar o cotidiano da Fazenda Santo Antônio que aguarda a chegada dos novos imigrantes. 
- BOA TARUDI, Manabe! O administrador estava procurando você.

Quando o "negro" fala em português com Manabe, o colono japonês veterano interrompe o trabalho e olhando para a esposa diz:

- Deve ser sobre os nôbo...

(Ishikawa, Tatsuzô. Sôbô: uma saga da imigração japonesa. Tradução Maria Fusako Tomimatsu et al. Cotia, São Paulo: Ateliê Editorial, 2008:240).

$\mathrm{Na}$ literatura japonesa sobre o Brasil, o emprego da língua portuguesa inserido nos diálogos é um recurso relativamente fácil e eficiente para proporcionar a atmosfera local, independentemente da língua utilizada no diálogo: malária, plantação, jacaré, camarada, cafezal, tatu etc.

Os japoneses não conviviam somente entre eles, em círculos fechados. Ao redor havia os camaradas negros que eram vizinhos imprescindíveis e, quando Manabe se dirige à residência do administrador que o chamava, ele encontra a alva garota italiana Maria, ocupada em lavar as roupas.

Nesse momento o administrador, que era italiano, apareceu montado em um cabaro.

Quanto chegou diante de uma valeta, incitou em japonês - $\hat{O}$, ichi, ni, no san! - e, após empinar o cavalo, pôs o cavalo a correr.

(2008:242)

Os imigrantes recém-chegados também precisariam, cedo ou tarde, se adaptar à vida no Brasil, assim como os demais compatriotas. Onatsu, protagonista da história, passa a enfrentar a sua nova vida no Brasil de modo que não lhe sobra tempo sequer de lembrar como era a sua vida em Akita ou do amor casual que tivera durante a viagem de navio. Magoichi, seu irmão mais novo, cumprimenta Maria com o seu português recém aprendido:

- Bom dia, senhorita! - gritou Magoichi. (p. 257)

Onatsu sente uma ponta de inveja ao perceber que, "apesar de Maria viver naquela colônia, ela parecia ser feliz." (p. 257) A introdução da personagem Maria no romance é como lançar uma luz no futuro dos recém-chegados imigrantes.

No entanto, no capítulo 3 existe outro personagem que, apesar de não estar em destaque, possui um papel muito importante no contexto da história: Kôtaro, o filho de Manabe. Além da filha Maria, o administrador italiano possui um filho caçula que tem quase a mesma idade do filho de Manabe. Há uma cena em que o filho do administrador vem contar para Manabe as traquinagens de Kôtaro: 
- Sabe, Manabe, seu filho Kotaro caiu daquele barranco e estava chorando.

- Hum, o que aconteceu?

- Non se. Mas depois estava descascando milho com faca e cortou a mão.

- Hum, cortou muito?

- Saiu sangue. Aí passou lama e parou de sangrar.

- Ah, é? ele no rio.

- E depois, pisou num pintinho da sua casa que acabou morrendo. Jogou

- Moleque estúpido! Onde ele está agora?

- Non se. Deve estar brincando com poruko. Ele gosta de brincar com poruko.

Trata-se de um episódio trivial que descreve com extrema sensibilidade a conscientização da presença do outro que ocorre entre o filho do administrador e o filho do colono japonês. O irmão mais novo de Maria, talvez pela disciplina imposta pela educação rigorosa dos pais, não gosta tanto de porcos como Kôtaro. Nas entrelinhas desta cena em que o irmão de Maria dedura as traquinagens de Kôtaro, revela-se não somente o desprezo que os imigrantes italianos mais abastados possuem em relação aos caboclos, mas também uma admiração velada pelo comportamento enérgico e a atitude despreocupada de Kôtaro que se assemelha a de um caboclo.

- Todos os japoneses são bonitos, mas quando moram muito tempo no Brasil, todos ficam encardidos que nem vocês. (p. 246) - diz ironicamente o cocheiro negro para Manabe durante o trajeto em que levava Onatsu e os imigrantes recém-chegados da estação de trem até a fazenda.

No processo de adaptação dos japoneses no Brasil, os caboclos, por sua vez, não eram apenas os seus mestres. $\mathrm{O}$ fato é que, sem a ajuda deles, os japoneses não conseguiriam sobreviver, principalmente, quando o assunto era o cultivo da terra e as técnicas de debulha. Os japoneses, assim como os colonos europeus, tornavam-se caboclos para se adequar a natureza do Brasil. Os caboclos eram os mestres da vida e, como tal, exerceram uma forte influência nos japoneses que para cá vieram. A ciência da higiene tentou veementemente controlar essa influência, mas o contágio era algo impossível de se conter. Tanto para os que, como Kôtaro, eram da geração 1,5 (crianças que chegaram pequenas e antes de frequentar a escola) quanto para os que eram da segunda geração, a autoconfiança do japonês, reforçado pelo ponto de vista higiênico e pelos ditames do modernismo, tornou-se uma mera superstição deveras incômoda.

A questão do "caboclo" que foi um assunto de interesse para Ishikawa Tatsuzô e Shimazaki Tôson no período pré-guerra deixou de o ser com a derrota 
do Japão, que perdeu suas antigas colônias. No entanto, a questão do dojin (nativo) ressurgiu com uma nova roupagem.

Para citar um exemplo temos a obra Amazon no uta (Canção da Amazônia, 1966) de Tsunoda Fusako (1910-2010). A autora se sensibilizou com o infeliz incidente ocorrido com as vinte famílias de imigrantes japoneses que pertenciam ao $4^{\circ}$ grupo de desbravamento das terras de Acará na Amazônia. Dentre as vinte famílias, apenas os nove integrantes da família do chefe do grupo permaneciam vivos, sendo que o destino dos demais foi o de "retornar para o Japão, morrer ou desaparecer."

Quando Tsunoda indagou aos colonos sobre o desbravamento ocorrido na região de Acará, a resposta unânime foi "não sei o que aconteceu". O que a autora deduziu a partir dessa resposta sucinta, e que a deixou triste, foi constatar que os colonos já haviam decidido permanecer naquela terra por estarem endividados até o pescoço.

A fuga de colonos durante a noite, após a chegada dos imigrantes do Kasatomaru, não era nenhuma novidade para os japoneses que estavam no Brasil. Mas, para os japoneses do pós-guerra, o desaparecimento de japoneses no interior do Brasil era uma história digna de um romance. Com a derrota do Japão, sete milhões de japoneses espalhados nos territórios asiáticos no pacífico foram deportados, o que significa que naqueles territórios a "naturalização" dos japoneses foi negada. Os casos de rendição do soldado Yokoi e de Onoda, ex-combatentes do antigo exército japonês, e a questão da identidade dos órfãos de guerra abandonados na China que eram, até então, assuntos que o Japão havia ocultado, ganharam grande repercussão na mídia, quando estes começaram a ser revelados.

As histórias de emigrantes japoneses que despareceram sem deixar vestígios e que as representações diplomáticas do Japão no país não conseguiam elucidar eram um material de extremo interesse para jornalistas escritoras como Tsunoda Fusako, que investigavam o destino dos compatriotas do antigo império japonês. Para a autora, a floresta tropical brasileira fazia parte do plano de expansão dos japoneses no hemisfério sul e estava relacionada com os locais de batalha realizados durante a Guerra no Pacífico. Isso porque mesmo após o término da guerra, o Ministério das Relações Exteriores continuou a intermediar a ida de imigrantes japoneses para a Amazônia, e não foram poucos os colonos que fincaram raízes naquela região.

Em Wairudo souru (Wild Soul, 2003), Kakine Ryôsuke (1966-) conta a história de um rapaz japonês que vivia numa colônia isolada no interior da Amazônia e que, posteriormente, resolve voltar ao Japão para se vingar do Gaimusho (Ministério das Relações Exteriores do Japão). Há, portanto, uma estratégia para tentar explorar o mistério que envolve os japoneses que desapareceram, transformando-os em personagens de obras literárias. 
Funado Yoichi (1944-), autor de romances de aventura e violência, narra a história de traição e desaparecimento de um japonês em sua obra Yamaneko no natsu (O verão do gato montês, 1984). O pai do rapaz era um militar que participou do golpe de Estado ocorrido no dia 26 de fevereiro de 1936 e o protagonista, que nasceu nesse dia, vem para o Brasil logo após o golpe. O jovem da geração 1,5 que foi criado no Brasil e que conseguiu superar a desorientação existente na comunidade nipo-brasileira durante a guerra, de repente, desaparece e, decorridos cerca de 30 anos, reaparece como um guerrilheiro diante de um jovem japonês que acabara de chegar. Na mesma linha, Funado Yoichi também escreveu um romance de aventura intitulado Densen naki tochi (Uma terra sem tradição, 1988) que conta a história de um guerrilheiro venezuelano. O enredo gira em torno do encontro casual entre o imigrante japonês da segunda geração e um rapaz japonês que pertencia ao exército vermelho. Funado Yoichi criou uma espécie de mito do nikkey ao descrevê-lo de modo hiperbólico e enigmático como "monstros" que vivem na América do Sul.

Essa técnica também foi adotada por Tsujii Naoki (1967-) em sua obra Miruton no Abeeria (As abelhas de Milton, 2006), que conta a história de um rapaz japonês que encontra em Saitama um nikkey da terceira geração que almeja se tornar um músico. Trata-se de uma técnica de dissimulação que tem a intenção de revelar à sociedade japonesa contemporânea como os japoneses da América do Sul se tornaram uns "monstros".

Paralelamente, há outra vertente de escrita que reforça as relações sexuais dos japoneses e dos nikkeys através do culto da beleza do corpo e a precocidade sexual da mulher brasileira. Daigo Massao (1935-) desenvolve esse tema com foco no Brasil e pode-se considerá-lo como o pioneiro desta vertente. Quando esteve no Brasil para coletar dados para compor a sua obra, Kita Morio (1927-2011) recebeu orientações de Daigo. Abaixo cito como exemplo um trecho da obra Kagayakeru aoki sora no shita de (Sob o céu esplêndido, 1986) de Kita Morio:

\footnotetext{
Próximo ao local em que Kiuchi capinava havia uma gigantesca árvore cujas raízes estavam expostas. Como se isso não bastasse, a terra formava um montículo. Ali formigas se movimentavam em profusão.

Ao observar o formato daquelas formigas estas lhe trouxeram uma lembrança horrível. A esposa do gerente geral da empresa denominada "Demônio das jutas" havia se suicidado com o amante caboclo tomando um veneno poderoso para matar saúvas. Se aquele incidente grotesco não tivesse acontecido e aquela mulher bonita não tivesse se suicidado com aquele nativo, eu não teria dormido com aquela filha do caboclo. Isso mesmo. Naquela noite em que o destino o fez ir ao baile da aldeia, por mais que ele estivesse bêbado, e por mais que a Carolina estivesse extremamente fascinante, o que fez com que Kiuchi abraçasse o seu corpo nu era porque em seu âmago reverberava os boatos daquele suicídio cometido pelos amantes.
} 
As relações sexuais entre os japoneses que viviam no Brasil e os nativos eram tacitamente negadas ou não reveladas conforme as rígidas regras da fechada sociedade japonesa ou, caso contrário, a pessoa era obrigada a deixar a comunidade.

O que acontecia frequentemente fora do Japão no período pré-guerra também ocorreu no Brasil no pós-guerra em relação aos japoneses e caboclos. Mas, esse tipo de história e as fofocas geradas por esse tipo de relação serão explorados nas literaturas de viagem barata que escritores japoneses escreviam sobre o Brasil.

A tendência de enaltecer o Brasil, que não vingou no pré-guerra, foi ressaltada, explorada e difundida na mídia japonesa do pós-guerra através das imagens do carnaval que enfatiza a beleza da mulher brasileira.

Nesse sentido, o relacionamento sexual com o "caboclo" que era uma escolha muitas vezes necessária para que o japonês pudesse sobreviver no Brasil, tornou-se um adereço para reforçar a sedução que permeia esse tipo de relação.

Os textos levianos escritos pelos escritores japoneses que descrevem sobre o japonês do Brasil não possuem afinidades com a literatura japonesa escrita no Brasil nesses últimos sessenta anos.

Os japoneses que escrevem romances sobre o Brasil possuem o interesse em descrever o comportamento dos japoneses e analisar os motivos de se tornarem o que são. E é justamente por não falar abertamente sobre essa questão é que se cria a ideia de um ser enigmático. Pode-se dizer que há uma ramificação intencional no modo como se aborda esse assunto entre os escritores japoneses no Brasil. Estes concentram o seu foco em descrever as experiências dos japoneses tentando revelar os segredos deste mistério.

Os escritores japoneses nascidos no Brasil, ao buscar novas possibilidades para a literatura japonesa tendo como referência autores como Ishikawa Tatsuzô e Shimazaki Tôson, deparam com a questão da influência do caboclo que continua sendo um assunto relevante.

Se o império japonês continuasse a dominar os vários territórios da Ásia no pós-guerra, certamente a mesma questão afligiria os nativos e os colonos japoneses, de modo que esse seria um problema ainda mais complexo que a questão do imperialismo.

Felizmente ou não, esse tipo de problema foi selado com a derrota do Japão na guerra. Por outro lado, em países desenvolvidos e de vanguarda tais como os Estados Unidos e o Canadá, a assimilação dos japoneses na sociedade americana no pós-guerra seguiu a direção da integração e não da nativização.

Em suma, a questão da "caboclização" transpôs a Segunda Guerra Mundial e se tornou um problema sério entre os japoneses, mas isso ocorreu somente na sociedade japonesa da América Central e da América do Sul. A literatura japonesa dos países latino-americanos não conseguiu se esquivar deste problema e, diferente 
dos escritores japoneses que usam esse assunto como um adereço, os que escrevem a literatura japonesa fora do Japão precisam enfrentar essa questão e, com isso, passaram a desenvolver uma nova vertente da literatura japonesa.

Durante a Segunda Guerra Mundial, os japoneses que viviam no Brasil foram alvo de repulsa por pertencerem a um país hostil e pelo apego aos ideais fanáticos do "mito da terra divina e eterna" (shinshûfumetsu). No final da guerra e no pós-guerra o conflito existente entre o kachigumi (grupo que acreditava que o Japão havia vencido a guerra) e o makegumi (grupo que aceitava a derrota do Japão) foi alvo constante dos holofotes, prejudicando ainda mais a imagem dos japoneses.

Negando a derrota do Japão, o grupo kachigumi praticava represálias contra os compatriotas considerados traidores e, em geral, o alvo eram os que se dedicavam à sericultura e o cultivo de hortelã. $\mathrm{O}$ kachigumi era um grupo de fanáticos que usava a força da arma e contava com a adesão maciça dos japoneses. Para enfrentá-lo havia o grupo dos makegumi que era a favor da assimilação como um meio de sobreviverem na sociedade brasileira. Este grupo estava ciente de que o Japão havia perdido a guerra por terem acesso às informações veiculadas pela mídia brasileira e pelos decretos promulgados no Japão.

No entanto, a cisão da comunidade japonesa em dois grupos ressalta a existência de um terceiro grupo que se disfarçava para escapar do estigma de pertencer a um país hostil e, também, se escondia do duplo olhar de vigilância da sociedade japonesa.

No Brasil, a maioria dos escritores japoneses é da primeira geração e pouquíssimos da segunda geração e posteriores, mas, dentre eles, gostaria de destacar a obra Imin ga teikô o ushinatta toki (1967) de Yamazaki Augusto (1925, Santos).

O protagonista nasceu na primeira metade da década de 30 e formou-se em Filosofia pela Universidade Imperial de Quioto e, segundo ele, “os imigrantes em geral partiam para o Brasil com o objetivo de ganhar dinheiro, mas eu tinha um ideal" e, autoconfiante, ele decide morar com o tio no interior do Brasil. "Se ele gostava de Nietzche, o melhor seria estudar na Europa, mas ele deve ter optado por dar uma de Zaratustra." No entanto, ao chegar ao Brasil imediatamente se decepciona: "Que lugar horroroso eu vim parar!".

No quintal de frente à cabana construída na terra que lhe foi atribuída, o protagonista encontra "dois montículos misturados com terra vermelha." Ao observá-los atentamente, ele descobre que aqueles montículos eram "três ou quatro crianças de cabelos crespos, com a barriga inchada que dormiam encolhidos como a abraçar porquinhos".

O colono veterano da fazenda diz "Não se assuste. Eles são caboclos; são como bichos, uma mistura de preto e índio. Obviamente, eles não sabem ler nem escrever e tampouco sabem a idade que têm. Para começar, nem são registrados no cartório". 
Para os que pretendiam fixar residência no Brasil, não convinha ficar assustado diante de um caboclo. Eles eram vizinhos muito importantes para os japoneses e eram eles que conheciam e tiravam dúvidas sobre a terra. E, se porventura, o japonês se tornar proprietário de terra e vir a administrá-la ele precisaria contratá-los como mão de obra barata, ainda que os caboclos não tivessem instrução.

Mas os olhos do protagonista fitaram o caboclo e assim permaneceram imobilizados como uma estaca. Ao observar o caboclo que se vestia de trapos desde que nasceu, andavam descalços na terra, eram desnutridos, tinham lombrigas e dormiam no chão do casebre, a única certeza que o protagonista tinha, ainda que o motivo fosse trivial, era a de que o seu senso de superioridade deveria ser preservado.

Mas o enredo da história se desenvolve de modo a descrever que, decorridos dez anos, o protagonista perde completamente a resistência de se tornar um caboclo. Ele tenta deixar a fazenda e vai para a cidade de São Paulo, mas logo descobre que o fato de ele não falar português limita-lhe as chances de conseguir trabalho. Em seguida, ele resolve trabalhar num lugar distante em que não havia japoneses. Nesse lugar ele recebe igualmente uma grande extensão de terra do proprietário brasileiro. Ele tenta domesticar habilmente os caboclos com o desejo de tentar algo novo, mas, por mais que ele se dedique ao trabalho, os caboclos contratados não atendem as suas expectativas.

- Você não acha que o Jé (protagonista) não regula bem da cabeça? Ele trabalha como um relógio. Não sei como ele aguenta.

Com o tempo, ele percebe que não adiantava desprezar os caboclos por considerá-los preguiçosos. E, repentinamente, ele se rende ao processo de assimilação. E sua vida toma um novo rumo ao se casar com a filha do proprietário. Apesar de ela ser a filha do proprietário, isso não significava que ela tinha instrução ou que fora educada na cidade.

Ela era o objeto de desejo dos jovens nativos e, no passado, houve até um caso de morte entre os seus pretendentes, mas "o fato de ela não ter se casado com algum nativo e ter escolhido um homem de outra raça, o protagonista não seria alvo da inveja deles." O protagonista recebe o batismo, casa-se na igreja, mas isso ocorre justamente no período em que o exército alemão invade a Polônia (setembro de 1939).

Após a invasão da Polônia, o Japão e os Estados Unidos entram na guerra e quando o navio brasileiro é atacado pelo submarino alemão e afunda, o Brasil declara guerra aos países do Eixo. Inúmeras medidas severas e restritivas são adotadas em relação aos imigrantes oriundos dos países do Eixo, como, por exemplo, a proibição de se reunirem em grupo, a retirada dos imigrantes que moravam na costa litorânea, falar uma língua que não fosse o português e a circulação dos imi- 
grantes era permitida somente com autorização. No entanto, para o protagonista que estava inserido entre os brasileiros, essas medidas em nada lhe afetaram. Durante os seis anos que antecedem o ano de 1945, a filha de quinze anos casa-se com o protagonista e se torna mãe de cinco filhos. Com a morte do sogro, o protagonista se torna um grande proprietário.

A despeito de ouvir de um sírio, que era dono de um bar, os boatos de que o Japão perdera na guerra, ele fingia não ligar "como se estivesse contemplando um incêndio do outro lado do rio" e, após a guerra, apesar de alguns japoneses morarem na vizinhança, ele não conseguia mais falar direito em japonês.

Em termos de aparência, seus cabelos estavam compridos a ponto de lhes cobrir as orelhas, a pele tinha uma coloração acobreada e seu olhar era vago e, seus olhos, fitavam algum ponto no espaço. Ao recordar como ele era quando veio do Japão, ele murmura para consigo mesmo:

- Naquela época, eu realmente era um idiota!

Ao escrever dessa maneira, há de se pensar que a "caboclização" dos japoneses foi um processo que ocorreu espontaneamente. Deve-se rir com desdém a habilidade que os "ignorantes" possuem para se preocuparem com o fato de vencer a guerra ou não, ou de se perturbarem se algo lhes convém ou não. Isso sim é que deve ser o ensinamento de Nietzche.

De meados da década de 1910 a 1920, os jornais japoneses publicados em São Paulo passam a promover uma coluna literária, período em que floresce a literatura japonesa no Brasil. Em 1930, começam a surgir alguns poetas e escritores dentre os que possuíam um conhecimento básico de literatura e que possuíam certa autonomia financeira. Após a visita de Shimazaki Tôson em São Paulo, surgiram duas revistas, uma de prosa denominada Chiheisen (Horizonte, 1937) e outra de poesias denominada Yashiki (Coqueiro, 1938). Mas, em julho de 1941, quando o isolamento do Japão no cenário internacional se intensifica, as publicações em língua estrangeira dos que pertenciam aos países do eixo são expressamente proibidas e a literatura japonesa no Brasil passa por um período sombrio.

Após a derrota do Japão na guerra, as publicações de jornais em língua japonesa sofrem as consequências da disputa entre o grupo kachigumi e makegumi e, durante um tempo, deixam de ser publicados até que o grupo dos esclarecidos (makegumi) consegue autorização para a publicação de jornais e revistas em língua japonesa.

Os jornais e as revistas de entretenimento eram os principais meios para divulgar a literatura japonesa e, até a criação da revista de literatura e artes Koronia Bungaku (Literatura da colônia) em 1966, os concursos de literatura promovidos pelos jornais tiveram uma grande participação dos imigrantes do pós-guerra, que 
começaram a chegar a partir de 1953, com a reabertura da imigração japonesa. Yamazato Augusto (1925-2012), por exemplo, atuou em diversas áreas e foi um autor que gostaria de destacar como um importante escritor que se dedicou a escrever sobre a questão do caboclo.

Assim como tive a oportunidade de conhecer Yamazato Augusto quando estive no Brasil em 2002, também conheci o escritor Matsui Tarô (1917-). Ele nasceu em Kôbe em 1917 e, quando criança, costumava observar os navios de imigrantes da ponte de atracação e de tanto vê-los partir começou a sonhar em vir para o Brasil. E foi em 1936 que ele e a família vieram para cá. No início, ele morou na cidade de Marília, que fora o local de maior concentração de pessoas que pertenciam ao grupo kachigumi no pós-guerra e, posteriormente, mudou-se para a cidade de Mogi das Cruzes. E foi em Mogi das Cruzes que ele realimentou o antigo gosto que tinha pela literatura e, nos tempos livres, passou a escrever.

O conto "Kyôken" (Cão raivoso, 1975), publicado na revista Koronia Bungaku na edição de número vinte e oito, tem como palco a Serra do Mar. O protagonista que nasceu na costa litorânea convive diariamente com os caboclos que moram nas florestas mantendo uma vida de autossubsistência e, ao mesmo tempo, convive com a sociedade japonesa, engajada em prosperar na vida vendendo produtos agrícolas, economizando e acumulando capital. O protagonista Tôgo passa a juventude desprezando e admirando os caboclos. Na verdade, Tôgo, quando jovem, apaixonou-se pela cabocla Ana. E ele a engravida. Mas, diante da intransigência de seu pai em aceitar o casamento deles, Tôgo deixa temporariamente a casa do pai e, após aguardar Ana deixar a montanha com outro homem, ele retorna e se casa com uma japonesa chamada Kimie. Ao retornar, o temperamento de Tôgo muda e ele passa a administrar a granja de seu pai. Um tempo depois, Ana retorna a vila trazendo consigo o filho jovem. Com o retorno deles, inicia-se uma sequência de tragédias. A esposa de Tôgo percebe que os ovos da granja estavam sendo roubadas. Tôgo, por sua vez, não consegue mais ficar tranquilo ao escutar os boatos de que Ana retornou com o filho Jorge. O cão de guarda da granja contrai raiva e espalha-se a notícias de que o ladrão de ovos foi mordido pelo cão. O protagonista fica apreensivo achando que o ladrão talvez seja o filho e sai a procura dele pela floresta. Ao se deparar com Jorge, este tenta fugir e fere Tôgo sem saber que ele era o seu próprio pai. Jorge acaba morrendo de febre aftosa. Trata-se de um conto com um final sangrento, digno da literatura de cordel.

Além de escrever romances, Matsui Tarô possui um grande interesse pelos estudos folclóricos de tradição oral. A literatura de cordel - conhecido no Japão como livro do folclore popular brasileiro - é uma publicação semelhante ao yomiuri. No Brasil, a literatura de cordel foi muito popular no início do período 
moderno, anterior à popularização da cultura escrita e as histórias são penduradas em cordas, o que deu origem ao nome "literatura de cordel", mas, num país em que o índice de alfabetização é baixo, esse tipo de literatura continua sendo muito popular. As histórias são narradas com o acompanhamento de uma viola e pode-se dizer que a literatura de cordel ainda é preservada nas cidades do interior como uma expressão tipicamente popular. Para se ter uma ideia, esse tipo de narrativa lembra os sermões, os contos narrados e o naniwabushi (tipo de toada acompanhado com o shamisen). Nessas histórias, um personagem tipo Robin Hood, amado pelo povo, trava uma luta de vida e morte fazendo com que os ouvintes se emocionem a ponto de chorar. Matsui Tarô traduziu para o japonês - em tom de naniwabushi - uma história típica da literatura de cordel que fala sobre o famoso Lampião, um revolucionário de Pernambuco:

Moça, olhe, aquele é lampião. Ele estende a mão e cumprimenta-a com um forte aperto de mão. Lampião diz: "Como vai, tudo bem?" A moça Maria se sente feliz em conhece-lo e seu coração palpita diante dele. (...)

$\mathrm{Na}$ sociedade minoritária, as fofocas que envolvem os compatriotas ocupam uma boa parte de suas vidas. No Brasil, os termos sen'botsusha (先没者) ou sen'môja (先亡者) que significa “os que morreram” passam a fazer parte do cotidiano de suas vidas. A vida dos emigrantes foi edificada sobre os inúmeros cadáveres dos que partiram. Há de se observar que é considerável o número de obras escritas na literatura japonesa no Brasil que trata da morte de imigrantes japoneses. Os imigrantes temiam a própria morte como se fossem soldados enviados para a linha de frente da batalha e toda vez que estavam diante da morte de algum compatriota que cruzou o oceano ou que trabalhavam juntos na roça, o medo da morte se tornava latente. O número de companheiros que não se sabia se morreram ou se desapareceram também era grande. Nesse tipo de sociedade, a morte ou o desaparecimento de um companheiro era como uma profecia que o alertava de que amanhã ele poderia ser o próximo. O romance de Matsui Tarô inspira-se na narrativa de tradição oral e se expressa em forma de romance japonês.

Dentre as suas obras, o mais extenso é Utsuro-bune (A barca vazia), publicado nas edições 27 a 47 da Revista Koronia bungaku, durante os anos de 1989-1994 e, assim como o conto "Cão raivoso", a história gira em torno de um protagonista que se casa com uma nissei e que ele a abandona após constantemente agredi-la. Deixando para trás a sociedade japonesa, o protagonista chega ao rio Paraná na divisa com Mato Grosso do Sul e, naquele local, conhece outra nissei que pos-

3 Matsui, Taro. A barca vazia. (Utsuro-bune). Tradução (japonês/português) de Lídia Ivasa. Organização Associação Cultural e Literária Nikkei Bungaku do Brasil e Michiyo Nakata. São Paulo: Escrituras, 2015. 
sui um bebê em fase de amamentação. Talvez pelo fato de estarem afastados da colônia japonesa, os dois se apaixonam, apesar de ela ter se tornado uma mulher completamente "cabocla". Um tempo depois, a mulher contrai a malária e vem a falecer. O protagonista assume cuidar do bebê e continua a viver no interior. Vive da pesca no rio e, vez por outra, vende o peixe numa vila próxima e, em troca, compra produtos de primeira necessidade, mas, certo dia, ocorre uma enchente na região e ele perde tudo. Com o pensamento de que "amanhã há de soprar o vento de amanhã", o protagonista descansa um tempo num fazenda e decide viajar como andarilho. A criança que ele cuidava sozinho desde pequeno havia crescido e fica aos cuidados de uma mulher da cidade.

O tema principal desenvolvido na literatura japonesa no Brasil centra-se em histórias de vida e morte dos japoneses da primeira geração que utilizavam a língua japonesa para se comunicarem e com a premente necessidade de manter a comunidade japonesa por perto. Eles lutavam contra a tentação de se tornarem caboclos e, ao mesmo tempo, tentavam se enquadrar nos moldes estabelecidos pela colônia japonesa. Algo que, para eles, era uma questão de necessidade absoluta. Assim como é o caso de Matsui Tarô no Brasil, aqueles que se dedicam à literatura, por mais que estejam adaptados à sociedade brasileira, jamais deixam de ser japoneses. Isso porque quanto mais tempo eles se dedicam à atividade literária escrita em sua língua materna, eles seguem uma direção oposta à assimilação ou adaptação à sociedade brasileira.

O conto Hairo (Caminho da destruição), publicado em 1938, edição 84 da Revista Nôson (Vila rural), conta a história de um japonês idoso que cria o filho com a intenção de fazê-lo herdar a granja, mas ele se casa com uma mulher brasileira. Essa mulher era extremamente ciumenta e brigava constantemente com o marido. Para evitar as brigas, o marido adquiriu o costume de dirigir o carro com alta velocidade para voltar o mais rápido possível para casa, quando precisava trabalhar até tarde. Até que um dia ele perde a vida num acidente de trânsito. A viúva se mostra triunfante quando o filho herda a granja. E para ostentar decide abrir um supermercado. O protagonista, indignado, arma uma bomba relógio que estoura no dia da inauguração do supermercado, provocando um enorme incêndio e, logo após o incêndio, ele desaparece. Esse tipo de história lembra os atuais short-short story (contos brevíssimos), mas, não deixam de ser histórias desagradáveis.

Os protagonistas das histórias de Matsui Tarô não são necessariamente japoneses. São histórias que, inclusive, podem servir de material para a literatura de cordel. Mas, se ainda existem escritores que continuam a escrever em língua japonesa no Brasil, é porque os japoneses querem acompanhar o momento em que os próprios japoneses vão deixar de sê-lo. Existe, portanto, um forte ímpeto e uma obsessão de acompanhar essa fase de transição. Se o protagonista for um japonês 
ou um nikkey, a questão da "caboclização" não será considerada como um perigo, pois sequer existe neles esse temor.

Para os japoneses que moram no Japão, o fato de imaginar que um dia o povo japonês se extinguirá é apenas uma fantasia considerada absurda. No entanto, no Brasil, o sentimento de iminente extinção não deixa de ser um sentimento real. Enquanto que os escritores japoneses no Japão possuem um grande interesse em descrever os japoneses que vivem fora de seu país como "monstros", os escritores japoneses no Brasil descrevem os antigos japoneses como "os mortos", ambos utilizando a língua japonesa como meio de expressão. No Brasil, com o decorrer do tempo, os japoneses foram mudando seu modo de viver e, aos poucos, foram assimilando o lado brasileiro.

Enquanto Shimazaki Tôson intuiu que havia algo de significativo no termo "caboclo", escritores como Matsui Tarô registram o que vem a ser esse complexo de perseguição existente nesse termo.

(tradução de Shirlei Lica Ichisato Hashimoto) 